\title{
РЕПРЕЗЕНТАЦЯ НЕГАТИВНИХ ЕМОЦЙ У ПИСЕМНОМУ МОВЛЕННІ ЯК СТИМУЛ МОДЕЛЮВАННЯ ПРАГМАТИЧНОЇ ПУНКТУАЦИЙНОЇ НОРМИ (НА МАТЕРІАЛІ АНАЛІЗУ ТВОРІВ І. НЕЧУЙ-ЛЕВИЦЬКОГО, М. ГОГОЛЯ, Ч. ДІККЕНСА)
}

\author{
ВІРА СЛІПЕЦКА \\ Дрогобицький державний педагогічний університет імені Івана Франка, \\ Дрогобич - Україна \\ vslipetska@ukr.net \\ REPREZENTACJA NEGATYWNYCH EMOCJI W MOWIE PISANEJ \\ JAKO BODZIEC DO MODELOWANIA PRAGMATYCZNEJ \\ NORMY INTERPUNKCYJNEJ (NA PRZYKŁADZIE UTWORÓW \\ I. NECZUJA-LEWICKIEGO, M. GOGOLA, CH. DICKENSA) \\ WIRA SLIPECKA \\ Państwowy Uniwersytet Pedagogiczny imienia Iwana Franki w Drohobyczu, \\ Drohobycz — Ukraina
}

STRESZCZENIE. Artykuł aktualizuje jeden z problemów lingwoemocjologii — sposoby przedstawienia negatywnych emocji i uczuć za pomocą odpowiednich "afektywnych znaków przestankowych" lub "emocjonalnych znaków przestankowych", modelujących transpozycję w dziełach literackich różnych lingwokultur (zwłaszcza ukraińskiej, rosyjskiej, angielskiej), co pozwala na wyróżnienie "interpunkcji emocjonalnej” jako składnika teorii lingwoemocjologii. Artykuł prezentuje również wyniki eksperymentu psycholingwistycznego, przeprowadzonego w audytorium studenckim.

\section{REPRESENTATION OF NEGATIVE EMOTIONS IN WRITTEN SPEECH AS STIMULUS OF MODELLING OF PRAGMATIC PUNCTUATION NORM (BASED ON THE WORKS WRITTEN \\ BY I. NECHUY-LEVYTSKYI, M. HOHOL, CH. DICKENS) \\ VIRA SLIPETSKA \\ Drohobych Ivan Franko State Pedagogical University, Drohobych - Ukraine}

\begin{abstract}
The article focuses on the actualization of one of the problem of linguistics of emotions - the ways of representation of the negative emotions and feelings by means of "the affective punctuation signs" or "the emotional punctuation signs" that model the transposition in fiction texts of different linguistic cultures (Ukrainian, Russian and English). This fact gives grounds to single out an emotional punctuation as a constituent of linguistics of emotions. The data of a psycho-linguistic experiment held among the students have been represented.
\end{abstract}

ктуалізуючи сучасну теорію лінгвоперсонології і в межах якої розгляда-
ючи структуру мовної особистості (MO), українська дослідниця Т. Кос-
меда ${ }^{1}$ виокремлює психотип, соціопсихотип, параметри мовної, кому-
нікативної та емоційної видів компетенцї МО, характеризує специфіку вия-

${ }^{1}$ T. Косм еда, Ego i Alter Ego Tapaca Шевченка в комунікативному просторі щоденникового дискурсу, Дрогобич 2012. 
ву національної самосвідомості в ії структурі, а також услід за сучасним російським ученим В. Шаховським ${ }^{2}$ акцентує увагу на необхідності опису homo sentins, або людини емоційної, повсякчас наголошуючи, що під час опису МО необхідно послідовно і всебічно враховувати невербальні чинники, які характеризують (виокремлюють) ту чи ту особистість серед інших у межах однієї конкретної лінгвокультури (ураховується суб'сктивний чинник), а також невербальні параметри, характерні для лінгвокультурної спільноти загалом, що дасть змогу порівняти в зазначеному аспекті різні лінгвокультури, спроектувавши порівняльно-зіставний метод і на чинник невербаліки, порівн.: „...спілкування передбачає не лише вербальні, але й невербальні засоби, паралінгвістичні - міміка, жести тощо”; , висновок про емоцію можна зробити тільки аналізуючи конкретну ситуацію [...] вербаліка + невербаліка + ситуація роблять зрозумілим те, що виражається, й для спостерігача, й для комуніканта"" Ці думки зокрема проілюстровані аналізом мовної особистості С. Руданського в монографії Т. Космеди, Т. Осіпової і Н. Піддубної Степан Руданський: феномен моделювання “живого” мовлення украйнівв , де є спеціальний розділ під назвою „Своєрідність омовлення невербаліки в дискурсі Степана Руданського", що окреслює й особливості омовлення невербаліки С. Руданського як МО й української нації загалом.

Зазначимо, що представниця наукової школи професора Т. Космеди Тетяна Осіпова ${ }^{6}$ доповнює типологію названої дослідниці параметром “паралінгвальна (невербальна) компетенція”, що заслуговує на схвалення, оскільки цей параметр є невід'ємним складником комунікативної компетенції насамперед homo sentins, оскільки під час омовлення емоцій, почуттів МО максимально актуалізує арсенал невербальних засобів, про що неодноразово писали класики мовознавства (В. фон Гумбольдт, О. Потебня, Л. Булаховський та ін.), хоч у кожній окремій лінгвокультурі зазначене має й певну специфіку вияву.

Загальновідомо, що представники слов'янських лінгвокультур характеризуються “гарячою емоційною температурою", пџо веде, напр., і до білып яскравого вияву невербальних параметрів, а англійська лінгвокультура традиційно окреслена, як “холодна", стримана в репрезентації почуттів, зокрема й невербаліки.

Під час аналізу усного мовлення зазначене можна безпосередньо спостерігати, а в мовленні писемному вказане описують, крім актуалізації системи типових вербальних засобів, ще й із залученням відповідних пунктуаційних знаків, що можуть репрезентувати пунктуацію авторську, авторські почуття та емоціï, на основі врахування цього й формуються нові прагматичні норми - нові способи застосування системи пунктуаційних знаків.

Мета наукової розвідки - схарактеризувати специфіку використання розділових знаків для фіксації вираження емоцій у художніх текстах різних лінгвокультур. Предмет - система пунктограм, що ії актуалізують письменники

${ }^{2}$ В. И. Шаховски й, Лингвистическая теория эмочий, Москва 2008.

${ }^{3}$ T. А. Кос меда, Ego i Alter Ego Tapaca Шевченка..., с. 21.

${ }^{4}$ Там само, с. 53 .

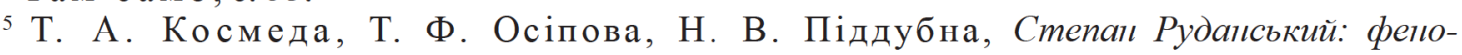
мен моделювания "эсивого" мовления українців, за наук. ред. проф. Т. А. Космеди, ХарківПознань-Дрогобич 2015.

${ }^{6}$ T. О сіп о ва, Вербалізація паралінгвальних засобів комунікації у творах Т. Г. Шевченка, [в:] „Лінгвістичні дослідження”, Зб. наук. праць Харків. нац. пед. ун-ту імені Г. С. Сковороди, за ред. проф. Л. А. Лисиченко, вип. 35, Харків 2013, с. 215-225. 
для вираження негативних емоцій у конкретних художніх текстах. Матеріалом дослідження обрано уривки 3 художніх творів I. Нечуя-Левицького Кайдамева сім'я, М. Гоголя Как поссорились Иван Иваныч с Иваном Никифоровичем, Ч. Діккенса The Pickwick Papers (Записки піквікського клубу) як найбільш характерних творів української, російської і англійської лінгвокультур XIX ст., у яких репрезентовано конфліктні ситуації.

Фахівці зауважують, що, безперечно, “емотивна компетенція мовної особистості виявляється і в ії вмінні породжувати в практиці комунікації емотивно коректні тексти"7, що є ознакою елітарної МО. Не можна не погодитися з думкою, що емоціï, почутmя впливають на своєрідний стиль мислення й мовлення людини ${ }^{8}$, а специфіка їхнього вияву є візитною карткою МО.

В. Апресян і Ю. Апресян відзначають, що емоції нелегко укласти в слова, оскільки „онтологічна складність зумовлює складність лінгвістичну: слову, що позначає емоції, практично неможливо надати прямого лексикографічного тлумачення"'.

Російський дослідник М. Олешков пропонує розмежовувати мову опису емоцій та мову вираження емоцій, що реалізуються емоційно зарядженою та контекстуально зумовленою лексикою, виконуючи, відповідно, номінативну й прагматичну функції ${ }^{10}$. I 3 цим слід погодитися. Послідовне врахування прагматичних функцій розділових знаків, безперечно, може допомогти в описі емоцій, хоч вони є і засобом їхнього подання.

Використання невербальних графічних знаків для вираження негативних емоцій у тексті зумовлює вияв прагматичних інтенцій. На думку I. Арнольд, текст, що містить багато пунктуаційних знаків, уважається емоційним ${ }^{11}$, тому, очевидно, можна розробити "шкалу" вияву ступеня емоційності тексту на базі врахування системи пунктуаційних знаків, що мають місце в канві певного тексту.

Графічні знаки, що слугують засобами вербалізації негативних емоцій додають тексту виразності, емоційності. Серед графічних знаків вираження негативних емоцій у художньому тексті основними $\epsilon$ тире, знак оклику, три крапки. Знак тире $є$ поліфункційним, його граматикалізований характер корелює 3 функцією уточнення.

Наголосимо, що Л. Булаховський виокремив прагматичні функції розділових знаків, що слугують репрезентації емоцій чи почуттів, увівши в лінгвістичний обіг поняття “афективний знак” і “емоціональний розділовий знак”, тим самим актуалізувавши проблематику лінгвоемоціології, порівн.: „У системі пунктуації окреме місце належить крапкам, знаку перерваної мови або в тім або в іншім відношенні не до кінця закругленої думки. Цей специфічно емоціональний розділовий знак уведений в європейську пунктуацію філософом чуття Жан-Жаком Руссо, і з цим знаком історично пов'язується новий етап європейського художнього стилю. Сфера його застосування - вирази хвилювань, афектів, лірично-забарвлені слова-назви і називні (номінативні) сполучення тощо”'; „нерідко крапки супроводжують такі афективні знаки, як знак пи-

${ }^{7}$ T. А. Космеда, Ego i Alter Ego Tapaca Шевченка..., с. 54.

${ }^{8}$ Там само, с. 54.

9 В. Ю Апресяп, Ю. Д. Апресяі, Метафора в семаптическом представлепии эмочий, [в:] „Вопросы языкознания”, 1993, № 3, с. 27-35.

${ }^{10}$ М. Ю. Олешков, Моделирование коммуникативного процесса, Нижний Тагил 2006, c. $228-229$.

${ }^{11}$ И. В. Арнольд, Семантика, стилистика, интертекстуальность, СПб. 1999, с. 233.

12 Л. А. Булахов сь кий, Украйнська пунктуація (розділові знаки), Київ 1947, с. 54. 
тання або оклику. Як і знаком паузи перед змістом здивовуючим те, що з ним суперничає, все більше витискуючи його в цій функції, — тире"13.

Отже, у системі пунктуаційних знаків особливе „місце належить крапкам, знаку перерваної мови або в тім, або в іншім відношенні не до кінця закругленої думки. Три крапки, зазвичай, слугують засобом графічного вираження мовчання - це невербальний маркер мовчання" 14.

Аналіз авторської вибірки 3 художніх текстів І. Нечуя-Левицького Кайдаиева сім'я, М. Гоголя Как поссорились Иван Иваныч с Иваном Никифоровичем, Ч. Діккенса Записки Піквікського клубу свідчить про те, що емотивність часто репрезентована трьома крапками, які увиразнюють подання негативної емоції гніву. Невербальний графічний знак три крапки функціонує поряд із вербальними засобами (іменники: дурень, дурак; дієслово: сердитись; прислівник сердито) для виокремлення негативної емоції гніву, напр.:

(1) - Мие странно, Иван Иванович: вы, кажется, человек, известный ученостью, а говорите, как недоросль. Что бы я за дурак такой...

- Садитесь, садитесь. Бог с ним! пусть оно себе околеет; не буду больше говорить ...;

(2) - Позвольте, Иван Иванович; ружье вещь благородная, самая любопытная забава, притом и украшение в комнате приятное ... .

- Вы, Иван Никифорович, разносились так с своим ружьем, как дурень с писаною торбою, - сказал Иван Иванович с досадою, потому что действительно начинал уже сердиться ${ }^{15}$.

(3) - Говори, дурню! Нема де втопиться. Як бог дасть, то і в калюжі втопишся, - сказав батько.

— Хіба з корчми йдучи ... - сердито сказав Карпо і тим натякнув батькові, щуо батько любить часто ходить до корчми.

— Ти, Карпе, ніколи не вдержиш язика! Все допікаєш мені гіркими словами ...;

(4) - Сватай Олену Головківну. Олена кругла, як ичибулька, повновидна, як повний місяць; в неї щзоки, мов яблука, зуби, як біла ріпа, коса, як праник, сама дівка здорова, як тур: як іде, то під нею аж земля стугонить.

- Гарна ... мордою хоч паџюки бий; сама товста, як бодня, а шия, хоч обіддя гни;

(5) - Та це твоя невісточка зварила обід тільки для себе та для Карпа. Вона хоче обідать окремо, - сказала Кайдашиха.

- Та нехай, про мене, обідас й сама, щзе й розпережеться, — сказав Кайдаш. - Нехай, про мене, з 'їсть оцюю кашу з гориком ... ${ }^{16}$.

Наведені приклади підтверджують слова Л. Булаховського і авторську гіпотезу про виокремлення негативних емоцій використанням трьох крапок. Після репрезентації негативу потрібна більша пауза для осмислення окресленого.

Нагадаємо, що емотивність графіки, яка окреслює значні емоційні (чуттєві) відхилення, ирийня'то називати транспозицією ${ }^{17}$.

\footnotetext{
${ }^{13}$ Там само, с. 54.

${ }^{14} \mathrm{~T}$. О. Ан охін а, Семантизація категорії мовчання в англомовному художньому дискурci, Віпшиц 2008, с. 84.

${ }^{15}$ Н.В.Гоголь, Как поссорились Иван Иваныч с Иваном Никифоровичем, [в:] Електронний pecypc: http:// www.klassika.ru/read.html?proza/gogol/ssora.txt\&page=9. (25.02.2016).

${ }^{16} \mathrm{I}$. Н ечу й - Лев иц к и й, Кайдамева сім'я, [в:] Електронний ресурс: http://www.ukrlib. com.ua/books/printthebook.php?id=74\&bookid=5\&part=5. (25.02.2016).

${ }^{17}$ И. В.А рн оль д, Семантика, стилистика, интертекстуальность, СПб. 1999, с. 301.
} 
В українському, російському та англійському художніх текстах специфічним $€$ поліфункційне використання тире та знака оклику під час опису сварки чи будьякої суперечки, конфліктної ситуації для вираження негативної емоції гніву.

Використання знака оклику і тире також дає змогу відчути підвищену емоційність висловлювання, необхідність виокремити емоцію специфічною паузою, ніби для того, щоб іï увиразнити, підготувати читача до іï оцінки і сприйняття, напр.:

(6) - Я не знаю, как вы, Иван Иванович, можете это говорить, на что мне свинья ваша? Разве черту поминки делать.

— Опять! без черта —_таки нельзя обойтись! Грех вам, ей-богу, грех, Иван Никифорович!

(7) — We are in a capital situation now, — said Mr. Picwick.

- Capital! - echoed both Mr. Snodgrass and Mr. Winkle.

- What are they doing now? - inquired Mr. Picwick.

- I-I rather think they are going to fire, — said Mr. Winkle.

— Nonsense, — said Mr. Picwick hastily.

- I-I really think they are, — urged Mr. Snodgrass, somewhat alarmed.

- Impossible, — replied Mr. Picwick ${ }^{19}$;

(8) - You - you are a nice rascal, aren't you? — exclaimed Wardle, breathless with passion ${ }^{20}$.

Тире семантизує психічний стан персонажів, виконуючи й прагматичні функції - створює ефект несподіванки. Семантизоване тире частіше міститься в кінці речення, створюючи анаколуфний силенціальний прагматичний ефект ${ }^{21}$, напр.:

(9) - Beg your pardon, sir, - said Wilkins, $=$ But $=$

- But what? Eh? — roared the captain.

- Who are you, you rascal? — said the captain, administering several pokes to Mr. Pickwick's body with the thick stick ${ }^{22}$.

Вираження емоції гніву увиразнено інтонацією, репрезентованою тире в середині речення. Важливо, що це простежуємо в позиції між словами, що виражають різко негативну семантику (оцінювально-кваліфікативні слова, що оновлюють найбільш абстрактне оцінювальне поняття $\left.{ }^{23}\right)$ : rascal — шахрай, негідник; ruffian - негідник, хуліган, бандит, напр.:

(10) - And I have only to add, sir, said Mr. Pickwick, now thoroughly angry, that I consider you a rascal and $a=a$ ruffian = and = and worse than a man I ever saw or heard of except that pious and sanctified vagabond in the mulberry livery.

- Ha! Ha! Said Jingle. Good fellow, Pickwick = fine heart = stout old boy = but must not be passionate = bad thing, very = bye-bye = see you again some day = keер up your spirits =now, Job = trot! ${ }^{24}$.

В українській, російській та англійській лінгвокультурах об'єктивносуб'єктивна природа знаків пунктуації, що слугують графічними засобами вер-

${ }^{18}$ Н. В. Гоголь, Указ. источник...

${ }^{19} \mathrm{Ch}$. Dickens, The Pickwick Papers, Penguin Books 1994, p. 72.

${ }^{20} \mathrm{Ch}$. Dickens, Ibidem, p. 156.

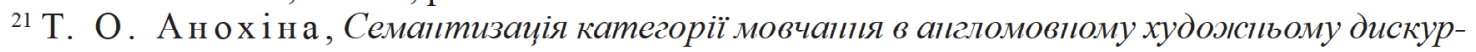
ci, Вінниця 2008, с. 85.

${ }^{22} \mathrm{Ch}$. Dicken s, Ibidem, p. 293.

${ }^{23} \mathrm{~T}$. Космеда, Аксіологічні аспекти прагмалінгвістики: формування і розвиток категорії очінки, Львів 2000.

${ }^{24} \mathrm{Ch}$. Dicken s, Ibidem, p. 394. 
балізації негативних емоцій, безперечно, мотивована системою комунікативнопрагматичних інтенцій мовців. Використання невербальних графічних компонентів, що слугують засобами вербалізації негативних емоцій, доповнюється вербальними елементами, діалогами, для яких характерна спонтанність та виражена емоційність.

Використовуючи наведені вище приклади (1-10), авторка дослідження провела психолінгвістичний експеримент серед студентів старших курсів інституту іноземних мов ДДПУ ім. І. Франка. Студентам було запропоновано оцінити доречність використання пунктуаційних знаків і пояснити, як ці знаки пов'язані з емоціями, що виникають у читача в процесі сприйняття відповідних фрагментів тексту. Більшість опитуваних (60 \%) відповіли, що три крапки вимагають від читача паузи, яка змушує акцентувати увагу на переданій вище інформації, з'являється час для більш глибокого усвідомлення емоційних інтенцій, які автор тексту намагається актуалізувати. Пунктуація в цьому разі вдало доповнює сприйняття вербальних засобів. Особливо виразно це простежують студенти у фрагментах текстів російської - (1), (2), (6) - і української - (3), (5), (6) - лінгвокультур. Тире вони сприймають як пунктуаційний знак, що більш виразно порівняно з трьома крапками акцентує увагу на емоціях у середині речення, особливо коли ці знаки тире немотивовані правилами. Грамотна людина, тобто та, яка знає чинні правила постановки пунктограм, завжди зауважить факт їхнього порушення, що змушує їі відчути особливу прагматику щодо репрезентації відповідних емоцій.

Видається, що подана думки студентів $є$ слушною, хоча частина 3 них (40 \%) взагалі не вважає, що пунктуаційні знаки певним чином впливають на сприйняття тексту. Вони гадають, що емоції можуть виражатися лише через знак оклику.

Звертаючи увагу на пунктуаційні знаки в текстах англомовної культури (7), (8), (9), - студенти вважають, що вони не завжди доречні, що пояснюємо фактом неповного володіння пунктуаційними нормами англійської мови, невмінням їх "прочитувати”, “декодувати” через недосконалий рівень знання. Крім того, тексти нерідної культури XIX ст., вочевидь, і сприймаються молодими людьми не зовсім адекватно.

Отже, спираючись на постулати відомих учених та авторський досвід аналізу пунктуаційних знаків, що увиразнюють сприйняття негативних емоцій, уважаємо, що є всі підстави в структурі лінгвоемоціології виокремити інтерпунктуацію емоцій (Л. Булаховський та І. Арнольд почали створювати, як було показано, метамову цього дослідницького аспекту — афективний розділовий знак, емоційний пунктуаційний знак, пунктуаційно емоційний текст та ін.). Це вимагає поглибленого вивчення прагматичних функцій розділових знаків, що, як бачимо, подібні в різних лінгвокультурах, однак мають і певну специфіку в репрезентації емоцій чи почуттів. 